\title{
Compatibilizando o uso de tecnologia em investigações com direitos fundamentais: o caso das interceptações ambientais
}

\section{Reconciling the use of technology in investigations with fundamental rights: the case of monitoring of public and private spaces}

\section{Jacqueline de Souza Abreu ${ }^{1}$}

Faculdade de Direito da Universidade de São Paulo - São Paulo/SP

jacqueline.abreu@usp.br

http://lattes.cnpq.br/6550261352169681

https://orcid.org/0000-0003-0450-4102

\section{Gianluca Martins Smanio ${ }^{2}$}

Faculdade de Direito da Universidade de São Paulo - São Paulo/SP

gianluca.smanio@usp.br

http://lattes.cnpq.br/2870717531871935

https://orcid.org/0000-0002-9219-1654

\begin{abstract}
Resumo: Avanços tecnológicos oferecem ferramentas para autoridades de investigação que levantam questionamentos à luz da proteção a direitos fundamentais. Este artigo estuda o processo de compatibilização pelo qual uma dessas ferramentas tem passado: as interceptações ambientais de sinais ópticos, acústicos e eletromagnéticos. Ainda hoje, a medida possui breve regulamentação jurídica no ordenamento brasileiro, mencionada no artigo $3^{\circ}$, II, da Lei n. ${ }^{\circ}$ 12.850/2013. Como meio de obtenção de prova caracterizado pelo caráter sigiloso e invasivo ao lar, à intimidade,
\end{abstract}

1 Doutoranda em Direito na Universidade de São Paulo, Departamento de Filosofia e Teoria Geral do Direito. Mestra em Direito pela University of California, Berkeley (EUA) e pela Ludwig-Maximilians-Universität München (Alemanha). Advogada em São Paulo - SP.

2 Mestrando em Direito na Universidade de São Paulo, Departamento de Direito Processual, subárea de Processo Penal. Advogado em São Paulo - SP. 
às comunicações e mesmo à autodeterminação informacional, é fundamental que seja dotado de regramento pormenorizado em lei a fim de evitar arbítrios incompatíveis com direitos fundamentais. Com o objetivo de contribuir para esse processo, este artigo reconstrói o processo de incorporação dessa medida investigativa ao direito brasileiro. A seguir, e a partir da lição do Tribunal Europeu de Direitos Humanos, discute-se a regulamentação da medida, engajando-se criticamente com o recente Projeto de Lei Anticrime.

Palavras-chave: interceptação ambiental; escuta ambiental; meio de obtenção de prova; direitos fundamentais; sigilo das comunicações.

ABSTRACT: Technological advances offer tools to law enforcement authorities that must be reconciled with the protection of fundamental rights. This article discusses the compatibilization process of one of these tools: the case of interception of optical, acoustic and electromagnetic signals in public and private spaces. This tool is briefly mentioned in Brazilian law, present only in the article 3, II, of the Lawn. ${ }^{\circ} 12.850 / 2013$. As an evidence gathering method, known for its secrecy and invasiveness, it is of the most importance to restrain its use with more detailed laws that reconcile the tool with fundamental rights. In order to contribute to this process, this article reviews how this monitoring tool has been incorporated into Brazilian law and discussed in scholarship. Next, in light of the lessons of the European Court of Human Rights, a provision found in the recent "Anti-crime" bill that would further incorporate the tool in Brazilian law is critically discussed.

KEYwORDs: interception of optical, acoustic and electromagnetic signals; surveillance; means to gather and obtain evidence; fundamental rights; secrecy of communications.

SuMÁRIO: Introdução; 1. Regime Jurídico Aplicável a Interceptações Ambientais; 1.1 Breve Histórico; 1.2. A tipicidade e a atipicidade dos meios de obtenção de prova; 1.3. Constitucionalidade: Interceptações Ambientais e Direitos Fundamentais; 1.3.1. Interceptações ambientais e a proteção da vida privada; 1.3.2. Interceptações ambientais e a proteção de ambientes públicos e privados; 1.3.3. Interceptações ambientais e a proteção ao sigilo das comunicações; 1.3.4. Análise crítica do impacto em direitos fundamentais; 1.4. Legalidade: Interceptações Ambientais e a Aplicação Analógica da Lei 9.296/1996; 2. Regulamentação: as lições do Tribunal Europeu de Direitos Humanos; 3. O Projeto de Lei Anticrime; Conclusão; Bibliografia. 


\section{INTRODUÇÃO}

A realização de interceptações ambientais levanta questionamentos jurídicos desde que gravadores foram desenvolvidos e se apresentaram como possível ferramenta de investigação para obtenção de provas. Nelas, há captação de conversa mantida entre duas ou mais pessoas presentes, fora do telefone ou da internet, em algum recinto, privado ou público. São, portanto, um exemplo clássico de como uma ferramenta tecnológica influencia a prática do direito processual penal. Como o avanço tecnológico não para, expandem-se também as possibilidades e capacidades da medida: pode ser e é utilizada não mais apenas para se referir à captura do fluxo de comunicação de voz entre presentes (sinais acústicos), mas também de imagens (sinais ópticos) e sinais eletromagnéticos de forma mais abrangente, capturados de um certo ambiente em tempo real.

O presente trabalho versa sobre uma questão permanente - e cada vez mais urgente, diante das crescentes potencialidades ofertadas pelo avanço tecnológico - sobre interceptações ambientais: como deve ser ajustado nosso regime jurídico para que discipline essa medida investigativa de modo compatível com direitos fundamentais? Primeiro, é analisado o regime jurídico hoje existente no Brasil aplicável a essa medida, tanto da perspectiva da constitucionalidade desse meio de investigação quanto de sua legalidade e tendo em vista tanto a doutrina quanto a jurisprudência. A seguir, o artigo apresenta a experiência do Tribunal Europeu de Direitos Humanos com o tema para destacar os principais aspectos levados em conta pelo tribunal ao analisar a compatibilidade desse tipo de medida restritiva com direitos humanos. Por fim, à luz das observações feitas nos tópicos anteriores, analisamos o Projeto de Lei Anticrime (Projeto de Lei n. ${ }^{\circ} 882 / 2019$ ) do atual Ministério da Justiça, que propõe a inserção do meio de obtenção de prova no diploma legal da Lei das Organizações Criminosas (Lei n. ${ }^{\circ}$ 12.850/2013).

Para qualquer pessoa preocupada em estudar o impacto da tecnologia no processo penal, a interceptação ambiental é um bom estudo de caso. Como esperamos mostrar ao longo do trabalho, esse meio de investigação foi incorporado ao ordenamento brasileiro sem maiores preocupações regulatórias - específicas do tipo de tecnologia em questão e com o contexto de sua aplicação. Por causa disso, a validade de provas 
produzidas por essa medida é ainda hoje questionada em diversos aspectos. Sem dúvidas, esse é um processo pelo qual passam e passarão diversas outras ferramentas tecnológicas que hoje se colocam à disposição de autoridades de investigação. As perguntas aqui colocadas e as observações extraídas podem ser, portanto, levadas para diversos outros casos.

\section{REGIME JURÍDICO APLICÁVEL A INTERCEPTAÇÕES AMBIENTAIS}

\subsection{Breve Histórico}

A noção de "interceptação ambiental" se inseriu na prática jurídica fundamentalmente com o propósito de qualificar um certo tipo de atividade de obter provas no âmbito de processo penal. Por isso se diz que sua natureza jurídica é a de meio de obtenção ou de pesquisa de provas, o que é feito em geral como providência cautelar como ato de investigação em fase pré-processual. ${ }^{3}$ Pela própria natureza dessa medida, ela é incompatível com o exercício do contraditório pleno, já que não haveria, via de regra, condições de atingir seu objetivo se fosse implementada com o conhecimento da pessoa ou das pessoas que se pretende monitorar.

O primeiro marco legal que trouxe a figura da interceptação ambiental ao ordenamento jurídico brasileiro foi a Lei n. ${ }^{0} 9.034 / 1995$, a antiga lei que regulava "meios de prova e procedimentos investigatórios que versem sobre ilícitos decorrentes de ações praticadas por quadrilha ou bando ou organizações ou associações criminosas de qualquer tipo" $\left(\operatorname{art.~} 1^{\circ}\right.$ ). Isso aconteceu quando, em 11 de abril de 2001, foi inserido pela Lei n. ${ }^{\circ} 10.217 / 2001$ o inciso IV no artigo $2^{\circ}$, prevendo "a captação e a interceptação ambiental de sinais eletromagnéticos, óticos ou acústicos, e o seu registro e análise, mediante circunstanciada autorização judicial”.

3 GOMES FILHO, Antonio Magalhães. Notas sobre a terminologia da prova (reflexos no processo penal brasileiro). In: YARSHELL, Flavio Luiz; MORAES, Maurício Zanoide (org.). Estudos em homenagem à professora Ada Pellegrini Grinover. São Paulo: DPJ, 2005. p. 303-318. p. 309; SIDI, Ricardo. A interceptação das comunicações telemáticas no processo penal. Belo Horizonte: D’Plácido, 2016. p. 60-62. 
No mais, na época, a doutrina tinha entendimento no sentido de aplicação, de forma análoga, do procedimento da Lei n. ${ }^{\circ}$ 9.296/1996, a Lei das Interceptações Telefônicas, ela mesma já alvo de severas críticas ${ }^{4}$. No julgamento do Inquérito 2.424, o Supremo Tribunal Federal considerou que a ausência de maior detalhamento do procedimento em lei não era razão de nulidade desse meio de prova. ${ }^{5}$

Em 2013, a Lei n. ${ }^{\circ} 9.034 / 1995$ foi ab-rogada pela Lei n. ${ }^{\circ}$ $12.850 / 2013$, que trouxe a nova regulamentação dos procedimentos probatórios referentes a organizações criminosas. Nela se admite que "em qualquer fase da persecução penal" será permitida a "captação ambiental de sinais eletromagnéticos, ópticos ou acústicos" como meio de obtenção de prova (art. $3^{\circ}$, inciso II). Considerando a legislação em que foi inserida, temos uma restrição do seu âmbito de aplicação apenas aos casos em que se constate a presença de organização criminosa ${ }^{6}$. No mais,

4 C.f.: SILVA, Eduardo Araujo da. Crime Organizado: procedimento probatório. $2^{\mathrm{a}}$ ed. São Paulo: Atlas, 2009. e DEZEM, Guilherme Madeira. Da prova penal: tipo processual, provas típicas e atípicas: (atualizado de acordo com as Leis 11.689/08, 11.690/08 e 11.719/08). Campinas: Millenium, 2008. p. 299-308. Em sentido contrário: MALAN, Diogo. Gravações Ambientais Domiciliares no Processo Penal. In: LIMA, José Corrêa de; CASARA, Rubens R. R. (coord.). Temas para uma perspectiva crítica do Direito: homenagem ao Professor Geraldo Prado. Rio de Janeiro: Lumen Juris, 2010. p. 350 e p. 355.

5 Veja-se trecho da ementa da decisão: "PROVA. Criminal. Escuta ambiental. Captação e interceptação de sinais eletromagnéticos, óticos ou acústicos. Meio probatório legalmente admitido. Fatos que configurariam crimes praticados por quadrilha ou bando ou organização criminosa. Autorização judicial circunstanciada. Previsão normativa expressa do procedimento. Preliminar repelida. Inteligência dos arts. $1^{\circ}$ e $2^{\circ}$, IV, da Lei no ${ }^{\circ}$ 9.034/95, com a redação da Lei $n^{\circ} 10.217 / 95$. Para fins de persecução criminal de ilícitos praticados por quadrilha, bando, organização ou associação criminosa de qualquer tipo, são permitidos a captação e a interceptação de sinais eletromagnéticos, óticos e acústicos, bem como seu registro e análise, mediante circunstanciada autorização judicial." SUPREMO TRIBUNAL FEDERAL. Inq. 2.424. Min Rel. Cezar Peluso. Data de julgamento 26 de março de 2009. Ver também "Informativo 529" do STF.

6 Eduardo Araújo da Silva defende que o legislador, ao estabelecer o meio de obtenção de prova na Lei . $^{\circ}$ 12.850/13, orientou-se pelo princípio da proporcionalidade, uma vez que a lei trata exatamente da apuração de crimes praticados por organização criminosa (SILVA, Eduardo Araújo da. Organizações Criminosas: Aspectos Penais e Processuais da Lei n. ${ }^{\circ}$ 12.850/2013. $2^{\mathrm{a}}$ ed. 
ao contrário do que ocorre para outros meios ali previstos, como a colaboração premiada, a ação controlada, e a infiltração de agentes, a lei não dedicou nenhuma seção para elencar os parâmetros que devem nortear a execução dessa medida. Comparada à redação original da lei anterior, nota-se que se omitiu inclusive a expressa referência à necessidade de "circunstanciada autorização judicial”, dando abertura para que a medida seja empregada sem decisão judicial prévia.

\subsection{A TIPICIDADE E A ATIPICIDADE DOS MEIOS DE OBTENÇÃO DE PROVA}

Essa previsão em si não encerra discussões sobre a juridicidade dessa medida - e, na verdade, essa opção legislativa repercute fundamentalmente na análise sobre a tipicidade das interceptações ambientais. Afinal, no Processo Penal Brasileiro, por mais que não vigore um sistema de taxatividade da prova penal, é importante que haja previsão legal desta e do procedimento pelo qual será colhida e inserida nos autos. Isso permite aos sujeitos processuais maior segurança, uma vez que podem tomar conhecimento, de forma precisa, dos requisitos necessários para a produção probatória, evitando eventuais nulidades procedimentais, além de deixar claro os direitos de cada um dos sujeitos, em especial as garantias processuais ${ }^{7}$.

Arantes Filho, após análise do desenvolvimento da discussão sobre tipicidade probatória nas doutrinas italiana e brasileira, traz que, para uma prova ser típica, é necessário que seja admissível, englobando a nominação e seus requisitos e o rito probatório, para assim formar o conjunto da disciplina legal do instituto. ${ }^{8}$ Logo, uma prova atípica é

São Paulo: Atlas, 2017.). Everton Luiz Zanella coloca que é meio de obtenção de prova "destinado a combater organizações criminosas" (ZANELLA, Everton Luiz. Infiltração de agentes no combate ao crime organizado: análise do mecanismo probatório sob o enfoque da eficiência e o garantismo. Curitiba: Juruá, 2016. p. 162.

7 DEZEM, Guilherme Madeira. Curso de Processo Penal. São Paulo: Revista dos Tribunais, 2015. p. 447.

8 ARANTES FILHO, Marcio Geraldo Britto. A interceptação de comunicação entre pessoas presentes. Brasília: Gazeta Jurídica, 2013. p. 44-45. 
aquela não catalogada ou regulada em lei ${ }^{9}$. Segundo a teoria ampliativa da atipicidade probatória, pode-se ter uma prova atípica tanto nos casos em que há previsão legal, mas não há regulamentação de seu procedimento probatório, quanto nos casos em que nem o meio de prova, nem seu procedimento tenham previsão legal ${ }^{10}$.

Nesse contexto, considera-se que, quanto à sua admissibilidade, interceptações ambientais são um meio de prova nominado, disposto no art. $3^{\circ}$, II, da Lei n. ${ }^{\circ} 12.850 / 2013$. No entanto, não há presença de requisitos, além da permissão de seu deferimento caso se constate presença de organização criminosa (art. $1^{\circ}$, caput, e definição do conceito de organização criminosa no $\S 1^{\circ}$ ), pressuposto simples frente ao seu caráter sigiloso e restritivo de garantias constitucionais, como se verá melhor à frente. Quanto ao rito probatório, não há lei que regulamente especificamente a interceptação ambiental. Temos, nesse sentido, o que a doutrina denomina de "prova nominada", por haver nomen juris previsto em lei, mas atípica, uma vez que não possui procedimento próprio ${ }^{11}$.

A doutrina aponta que o motivo da omissão legislativa é possível de ser encontrado na exposição de motivos do projeto que originou tal lei: "o legislador entendeu desnecessária a criação de procedimento probatório autônomo para a captação ambiental de sinais eletromagnéticos, óticos ou acústicos, por entender que lhe é aplicável, por analogia,

9 GOMES FILHO, Antonio Magalhães. Notas sobre a terminologia da prova (reflexos no processo penal brasileiro). In: YARSHELL, Flavio Luiz; MORAES, Maurício Zanoide (org.). Estudos em homenagem à professora Ada Pellegrini Grinover. São Paulo: DPJ, p. 303-318, 2005. p. 314.

10 Segundo Dezem, para a posição ampliativa, "tem-se que uma prova é atípica em duas situações:(1) quando ela seja prevista no ordenamento, mas não o seja seu procedimento probatório; (2) quando nem ela nem seu procedimento probatório sejam previstos em lei". (DEZEM, Guilherme Madeira. Curso de Processo Penal. São Paulo: Revista dos Tribunais, 2015. p. 445).

11 DEZEM, Guilherme Madeira. Da prova penal: tipo processual, provas típicas e atípicas: (atualizado de acordo com as Leis 11.689/08, 11.690/08 e 11.719/08). Campinas: Millenium, 2008. p. 156-157. Arantes Filho delimitou a prova atípica aos seguintes casos: "a prevista em lei, sem o respectivo procedimento probatório (próprio ou por remissão), a referida nominalmente em lei e a não referida em lei.". Já a nominada "é a prevista em lei, com ou sem delimitação de procedimento probatório." (ARANTES FILHO, Marcio Geraldo Britto. A interceptação de comunicação entre pessoas presentes. Brasília: Gazeta Jurídica, 2013. p. 45). 
o rito da interceptação de comunicações telefônicas e telemáticas (Lei 9.296/1996)". ${ }^{12}$ O problema é que, assim como no passado, a aplicação analógica de tal lei para interceptações ambientais não é pacífica na doutrina, apesar de a equiparação ser frequente na jurisprudência; voltaremos a este ponto mais a frente.

Por ora, frente a esse cenário, cabe analisar dogmaticamente se e em que condições interceptações ambientais podem ser utilizadas como meio de prova, segundo o paradigma constitucional. Para tanto, seguiremos o cotejo analítico avançado por Dezem. Em sua obra, ele estipula duas condições, de maneira cumulativa, para que a atipicidade seja lícita e o meio de investigação de prova possa ser utilizado: em primeiro lugar, não pode haver violação a qualquer direito fundamental individual ao longo de sua produção; em segundo lugar, deve haver meio de prova típico, ou seja, admissível e com procedimento probatório definido em lei, que possa ser aplicado analogicamente. ${ }^{13}$ Nas subseções que seguem, discutiremos esses pontos. Ao ingressarmos nessa discussão, é importante ter em mente que provas obtidas em violação a normas constitucionais, substantivas ou processuais, são inadmissíveis. ${ }^{14}$

\subsection{Constitucionalidade: Interceptações Ambientais e Direitos FUNDAMENTAIS}

Uma preocupação transversal a todos os tipos de interceptação é a questão da constitucionalidade dessa medida, conquanto afeta direitos fundamentais. Nessa seção, cuidamos de analisar os direitos constitucionais implicados na execução de medidas de interceptação ambiental a partir

12 MALAN, Diogo. Da Captação Ambiental de sinais eletromagnéticos, óticos, ou acústicos e os limites relativos à privacidade. AMBOS, Kai; ROMERO, Eneas (coord.). Crime Organizado: Análise da Lei 12. 850/2013. São Paulo: Marcial Pons, 2017. p. 51-81. p. 57.

13 DEZEM, Guilherme Madeira. Da prova penal: tipo processual, provas típicas e atípicas: (atualizado de acordo com as Leis 11.689/08, 11.690/08 e 11.719/08). Campinas: Millenium, 2008. p. 275 e ss.

14 GOMES FILHO, Antonio Magalhães; BADARÓ, Gustavo. Prova e sucedâneos da prova no processo penal brasileiro. Revista Brasileira de Ciências Criminais, São Paulo, v. 15, n. 65, p. 175-208, mar./abr., 2007. p. 198. 
do rol de direitos fundamentais encontrados na Constituição Federal brasileira de 1988: o direito à privacidade ${ }^{15}$, o direito à inviolabilidade do domicílio ${ }^{16}$ e o direito ao sigilo das comunicações. ${ }^{17}$

\subsubsection{INTERCEPTAÇÕES AMBIENTAIS E A PROTEÇÃO DA VIDA PRIVADA}

Um primeiro direito constitucional que pode ser afetado por interceptações ambientais é aquele previsto no inciso $\mathrm{X}$ do art. $5^{\circ} \mathrm{da}$ Constituição Federal, que protege a intimidade e a vida privada. Trata-se fundamentalmente de proteção ao conjunto de informações sobre as quais o indivíduo deve ter poder de controle sobre guardar em sigilo para si ou comunicar, com quem, onde e nas condições que quiser. ${ }^{18} \mathrm{E}$ por isso que sequer se questiona a legalidade de interceptações quando há notificação e consentimento daqueles que estão sendo gravados. Neste caso, os atores afetados dispõem sobre seu direito, concordando com o registro de informações por eles comunicadas. Em sendo assim, não há que se falar, a princípio, em interferência nesse direito mesmo quando as comunicações registradas dizem respeito a imagens e conversas que possam ter conteúdo íntimo, desde que a coleta e o uso dessas informações permaneçam vinculados aos fins a que foram coletados e com os quais os interceptados concordaram.

15 “Art. $5^{\circ}, X$ - são invioláveis a intimidade, a vida privada, a honra e a imagem das pessoas, assegurado o direito à indenização pelo dano material ou moral decorrente de sua violação."

16 "Art. 5", XI - a casa é asilo inviolável do indivíduo, ninguém nela podendo penetrar sem consentimento do morador, salvo em caso de flagrante delito ou desastre, ou para prestar socorro, ou, durante o dia, por determinação judicial."

17 “Art. 5, XII - é inviolável o sigilo da correspondência e das comunicações telegráficas, de dados e das comunicações telefônicas, salvo, no último caso, por ordem judicial, nas hipóteses e na forma que a lei estabelecer para fins de investigação criminal ou instrução processual penal". Ver ABREU, Jacqueline de Souza; ANTONIALLI, Dennys. Vigilância sobre as comunicações no Brasil: interceptações, quebras de sigilo, infiltrações e seus limites constitucionais. São Paulo: InternetLab, 2017. p. 21.

18 SILVA, José Afonso. Curso de Direito Constitucional. $32^{\text {a }}$ ed. São Paulo: Malheiros, 2009. p. 206. 
Na ausência de notificação e de consentimento, as interceptações interferem nesses direitos à intimidade e vida privada, especialmente quando utilizadas para obter informações que os interlocutores afetados buscam manter sobre controle quanto à sua publicidade. Quanto mais sensíveis as informações obtidas, maior a invasão à privacidade concretizada pela interceptação ambiental.

\subsubsection{INTERCEPTAÇÕES AMBIENTAIS E A PROTEÇÃO DE AMBIENTES PÚBLICOS E PRIVADOS}

Quando a interceptação ambiental ocorre em local privado, como um domicílio, seja ele familiar ou profissional, os interesses relacionados à inviolabilidade do domicílio, protegidos no art. $5^{\circ}, \mathrm{XI}$, da Constituição Federal, estão especialmente presentes. Essa característica faz com que o grau da invasão decorrente de uma interceptação de ambiente privado seja especialmente maior por acarretar intromissão em relações domésticas, familiares, de esfera privada, já que se entende que são nesses espaços que se realizam condutas que servem para o desenvolvimento individual. ${ }^{19} \mathrm{O}$ mesmo acontece em certos domicílios profissionais e, principalmente, naqueles resguardados pela proteção de sigilo profissional. ${ }^{20}$

Mais difícil é o caso em que a interceptação ambiental ocorre em ambiente público: algum direito é afetado? Nesse caso, apesar de ainda incipiente no Brasil, principalmente em razão da falta de previsão expressa no texto da constituição e da cultura jurídica ainda pouco sensível ao tema, o interesse de "privacidade" afetado traduz-se, pelo que se vê no direito comparado, na autodeterminação informativa, termo utilizado para se referir ao direito com o qual se pretende garantir controle de indivíduos sobre produção e uso de dados que lhe digam respeito, concepção que foi desenvolvida doutrinária e jurisprudencialmente frente

19 Ver SILVA, José Afonso. Curso de Direito Constitucional. 32a Ed. São Paulo: Malheiros, 2009. p. 207; ROXIN, Claus. La prohibición de autoincriminación y de las escuchas domiciliarias. Buenos Aires: Hammurabi, 2008. p. 91.

20 SILVA, José Afonso. Curso de Direito Constitucional. 32 ${ }^{\mathrm{a}}$ Ed. São Paulo: Malheiros, 2009. p. 207-208. 
aos avanço da tecnologia e dos riscos decorrentes da coleta massiva e do uso inesperado de dados pessoais. ${ }^{21}$

A noção relevante para a matéria de interceptações ambientais é que, mesmo que ao ingressar no domínio público se abra mão do domínio exclusivo de algumas informações pessoais daqueles com quem se compartilha o espaço público, quando um meio permanente registra o que é feito em público, algo de diferente acontece. Isso porque, sem o uso de tecnologias de gravação, as informações que compartilhamos em público são retidas apenas temporariamente na memória de um número reduzido de pessoas. Quando há o registro permanente por meio de gravação de áudio ou vídeo, aumentam-se os riscos aos quais se está exposto: desde exposição a um número inesperado de pessoas até à agregação de dados e extração de análises de comportamento que podem ser usados contra o próprio indivíduo, em estratégias comerciais ou mesmo políticas. ${ }^{22}$ Por essa razão, mesmo nesse caso há ou pelo menos pode haver restrição de interesse relevante, se a autodeterminação informativa for interpretada como mais uma faceta do direito de personalidade.

\subsubsection{INTERCEPTAÇÕES AMBIENTAIS E A PROTEÇÃO AO SIGILO DAS COMUNICAÇÕES}

Claramente, pela linguagem do inciso XII do art. $5^{\circ}$ da Constituição Federal, as interceptações de comunicações telefônicas são medidas que o constituinte admitiu como, pelo menos em princípio, constitucionais, desde que observados certos parâmetros previstos em lei. ${ }^{23} \mathrm{O}$ que dizer

21 Ver DONEDA, Danilo. Da privacidade à proteção de dados pessoais. São Paulo: Renovar, 2006. p. 204; MENDES, Laura Schertel. Privacidade, proteção de dados e defesa do consumidor. São Paulo: Saraiva, 2014. p. 32.

22 Ver MOORE, Adam D. Privacy Rights: Moral and Legal Foundations. Pennsylvania: Penn State University, 2010. p. 90-91.

23 Com um atraso de quase oito anos, a lei que regulamentou a exceção ali prevista para interceptações telefônicas foi aprovada e assim foram criados parâmetros para utilização desse meio de obtenção de prova. A Lei 9.296 de 1996, no entanto, também 'inovou' de outras formas e logo trouxe questionamentos sobre sua constitucionalidade: ela estendeu o seu âmbito de aplicação não só a interceptação do fluxo de comunicações telefônicas, mas também ao fluxo de "comunicações em sistemas de informática e telemática” (art. 1, parágrafo único), isto é, a comunicações eletrônicas. Diante disso, a constitucionalidade 
das interceptações ambientais? Seriam as interceptações ambientais conciliáveis com o art. $5^{\circ}$, inciso XII?

Nesse contexto, vale lembrar que Ferraz Júnior defendia que as interceptações telefônicas eram as únicas que a Constituição havia admitido porque comunicações telefônicas não se perenizam em meio algum. ${ }^{24}$ Nessa mesma linha, Badaró endossa o entendimento de que comunicações eletrônicas de navegação na internet, quando não se 'registram' em nenhum documento, também poderiam ser interceptadas por esse mesmo motivo. ${ }^{25}$ Se é essa a racionalidade, também é possível dizer que comunicações ocorridas entre presentes, em recinto público ou privado, não se perenizam, de modo que seria ainda necessário e autorizado pela constituição garantir a possibilidade de haver interceptação ambiental.

Sobre essa questão, é importante notar que não é imediatamente evidente que questões relacionadas ao inciso XII do art. 5 da Constituição Federal podem ser suscitadas. Isso porque interceptações ambientais afetam comunicações entre presentes - não ocorridas de forma mediada.

de tal dispositivo foi contestada com base no entendimento baseado no texto literal do inciso XII do art. 5 de que só o fluxo de comunicações telefônicas poderia ser restringido para fins de persecução penal. SUPREMO TRIBUNAL FEDERAL. Ação Direta de Inconstitucionalidade n. 1488-9/DF, Min. Néri da Silveira, julg. em 07.11.1999. Entretanto, por ter julgado ilegítima a parte proponente da ação (Associação Nacional dos Delegados de Polícia), foi negado prosseguimento ao caso; nova ação de mesmo escopo (ADI 4.112/ DF) aguarda julgamento desde 2008. Atualmente, o Marco Civil da Internet (Lei 12.965 de 2014 ), em seu art. $7^{\circ}$, inciso II também prevê a possibilidade de interceptação do fluxo de comunicações pela Internet, mediante ordem judicial, "na forma da lei" (no que se vê uma referência à Lei 9.296/96). O Congresso Nacional, portanto, previu já em pelo menos dois regramentos a possibilidade de interceptação telemática, que também já é prática investigativa corriqueira há muitos anos. Apesar da inércia do STF sobre essa, o próprio tribunal já admitiu tacitamente a constitucionalidade dessa medida ao julgar recursos criminais em controle concreto de constitucionalidade.

FERRAZ JR., Tercio Sampaio. Sigilo de Dados: o direito à privacidade e os limites da função fiscalizadora do Estado. Revista da Faculdade de Direito da Universidade de São Paulo, São Paulo, v. 88, p. 439-459, 1993.

BADARÓ, Gustavo. Interceptação de comunicações telefônicas e telemáticas: limites ante o avanço da tecnologia. In: LIMA, José Corrêa de; CASARA, R. R. Rubens. (coord.). Temas para uma perspectiva crítica do direito: homenagem ao Professor Geraldo Prado. Rio de Janeiro: Lumen Juris, 2010. p. 483-499 
Isso é relevante porque o sigilo ali garantido, textualmente, relaciona-se ao fluxo de informações comunicadas e transmitidas pelos meios lá citados, isto é, as correspondências, mensagens telegráficas, dados e telefonemas, meios típicos de comunicação entre ausentes. Apenas se o dispositivo for interpretado tendo em vista o valor que busca proteger - isto é - um direito de limitar os destinatários de uma comunicação, não importa a forma que tome, em detrimento da literalidade textual, é que se pode dizer que esse direito é implicado por interceptações ambientais. Cabe ressaltar, neste ponto, que a posição adotada depende da teoria da interpretação adotada pelo intérprete que, como visto, pode rejeitar ou aceitar a proposição de que o direito ao sigilo previsto no inciso XII está em jogo.

\subsubsection{ANÁLISE CRÍTICA DO IMPACTO EM DIREITOS FUNDAMENTAIS}

O objetivo dessa subseção foi mostrar que interceptações ambientais impactam diversos direitos fundamentais previstos na Constituição Federal. Na linha do raciocínio de Dezem, citado acima, para quem a atipicidade de um meio de obtenção de prova é lícita apenas se não violar direitos fundamentais, temos de concluir que essa condição não foi satisfeita. Por restringirem direitos fundamentais, as interceptações ambientais necessariamente precisariam ser típicas, rigorosamente regulamentadas em lei, além de sujeitas ao crivo judicial.

Esse não é o único paradigma que justifica tal conclusão. Dentro do modelo de avaliação de constitucionalidade de medidas restritivas a direitos fundamentais popularizado por Alexy, o fato de que uma medida estatal (aqui, um meio de investigação) interfere em direitos fundamentais faz com que o ônus na justificação dessa medida aumente. Requisito básico para isso é a atenção ao princípio da legalidade - a necessidade de que a medida seja não só prevista, mas procedimentalizada em lei, de forma a incluir salvaguardas que garantam a proporcionalidade dessa medida. Só assim é que interceptações ambientais poderiam ser fundamentadas como admissíveis em um Estado constitucional de Direito. ${ }^{26}$ Isso pode ser atestado em decisão do Tribunal Federal

26 ALEXY, Robert. Teoria dos Direitos Fundamentais. 2a ed. São Paulo: Malheiros, 2015; ALEXY, Robert. Constitutional Rights and Proportionality. 
Constitucional da Alemanha, que já se debruçou sobre o tema e chegou a declarar inconstitucional lei que previa interceptação ambiental em domicílios, mas não continha salvaguardas suficientes para resguardar a proporcionalidade dessa medida. ${ }^{27}$

Em que pese isso, a realidade jurisprudencial brasileira, como já acenado, é outra. No Inquérito 2.424, decidido em 2010 pelo Supremo Tribunal Federal, considerou-se que o ingresso da autoridade policial em domicílio profissional (no caso, escritório de advocacia), no período noturno para instalação de equipamento de captação, não torna nula a prova assim obtida quando a medida tiver sido autorizada por decisão judicial baseada em suspeita grave da prática de crime. Segundo a Corte, essa situação não implicaria violação da Constituição pois, no caso, o próprio advogado é suspeito da prática de crime, sobretudo concebido e consumado no âmbito desse local de trabalho. Isso significa, em outras palavras, que o STF considerou suficiente o modelo do atual regime legal em vigor - que nomeia esse meio de investigação, sem regulamentá-lo. E isso mesmo em um caso com o nível de sensibilidade maior, por envolver a questão sobre a extensão do sigilo profissional de advogados.

Como se pode notar da decisão, entretanto, o STF colocou certas balizas. A inviolabilidade do domicílio só é afastada quando há legítima suspeita de envolvimento em atividade ilícita, o que deve ser avaliado por um magistrado. A nosso ver, a melhor maneira de garantir que isso não dê lugar a abusos e arbitrariedades seria pela regulamentação detalhada em lei, que justamente serviria para nortear a atuação de controle judicial nesse sentido e elencaria outros requisitos e métodos que garantissem a conciliação com todo o sistema constitucional brasileiro, principalmente seus princípios e garantias fundamentais. Considerando essa preocupação, vale analisar a possibilidade de aplicação analógica da Lei n. ${ }^{0}$ 9.296/1996.

Revus (Online), v. 22, p. 51-65, 2014. Disponível em: <http://revus.revues. org/2783>. Acesso em: 01. set. 2019. https://doi.org/10.4000/revus.2783

27 BVerfGE 109, 279-391. Decisão de 3 de março de 2004. Disponível em: <http://www.bverfg.de/entscheidungen/rs20040303_1bvr237898.html>. Acesso em 26 de maio de 2018. 


\subsection{Legalidade: Interceptações Ambientais e Aplicação Analógica da LEI N. ${ }^{\circ} 9.296 / 1996$}

A seção anterior apresentou como interceptações ambientais afetam direitos fundamentais. Seguindo o teste proposto por Dezem para avaliar se um meio de prova atípico pode ser utilizado, outro aspecto a se analisar é se a Lei das Interceptações Telefônicas poderia ser aplicada analogicamente para interceptações ambientais. Parte da doutrina responde negativamente, enquanto outra parte determina ser imperioso o uso análogo, no que couber ${ }^{28}$.

Silva, em sua obra, considera que a Lei n. ${ }^{0} 9.296 / 1996$ deve ser aplicada analogicamente, no que couber, uma vez que tanto a interceptação telefônica como a ambiental são meios de obtenção de prova que acarretam a violação da intimidade e da vida privada do investigado ${ }^{29}$. É o posicionamento com o qual Marcelo Mendroni e Everton Zanella também compactuam, desde um ponto de vista pragmático: como não possui procedimento probatório próprio, resta à interceptação ambiental seguir a mesma lógica da interceptação telefônica ${ }^{30}$. Tal posicionamento vai ao encontro do entendimento do legislador, conforme já dito, previsto na exposição de motivos do projeto original da Lei n. ${ }^{\circ}$ 12.850/2013, pela desnecessidade de procedimento específico frente ao fato de a matéria estar supostamente suficientemente prevista na Lei n. ${ }^{\circ}$ 9.296/1996.

28 Em sentido favorável: SILVA, Eduardo Araujo da. Crime Organizado: procedimento probatório. $2^{\mathrm{a}}$ ed. São Paulo: Atlas, 2009. p. 111. No sentido contrário: ARANTES FILHO, Marcio Geraldo Britto. A interceptação de comunicação entre pessoas presentes. Brasília: Gazeta Jurídica, 2013. p. 288-296; BADARÓ, Gustavo. Processo Penal. $4^{\mathrm{a}}$ ed. São Paulo: Revista dos Tribunais, 2015. p. 506; MALAN, Diogo. Da Captação Ambiental de sinais eletromagnéticos, óticos, ou acústicos e os limites relativos à privacidade. AMBOS, Kai; ROMERO, Eneas (coord.). Crime Organizado: Análise da Lei 12. 850/2013. São Paulo: Marcial Pons, 2017. p. 51-81. p. 60-61.

SILVA, Eduardo Araujo da. Crime Organizado: procedimento probatório. $2^{\mathrm{a}}$ ed. São Paulo: Atlas, 2009. p. 111.

30 MENDRONI, Marcelo Batlouni. Crime organizado: aspectos gerais e mecanismos legais. $6^{a}$ ed. Rio de Janeiro: Forense; São Paulo: Atlas, 2016. p. 246-247 e ZANELLA, Everton Luiz. Infiltração de agentes no combate ao crime organizado: análise do mecanismo probatório sob o enfoque da eficiência e o garantismo. Curitiba: Juruá, 2016. p. 162-164. 
Tais argumentos devem ser avaliados com cautela. Como se viu, a interceptação ambiental é um meio de investigação que impacta diversos direitos fundamentais, com potencial de ser mais invasivo que a interceptação telefônica, por mais que em ambos os casos os interesses violados sejam semelhantes - intimidade e vida privada do investigado. Além disso, a aceitação pragmática da interpretação analógica apenas evita, sem enfrentar, o problema jurídico (de se utilizar um meio de investigação atípico que afeta seriamente direitos fundamentais), o qual permanece. Ademais, há diferenças cabais de objeto e de meio operacional, que dificultam a aplicação analógica da Lei das Interceptações Telefônicas.

Em primeiro lugar, quanto ao objeto: uma interceptação telefônica versa sobre conversas mediadas por um aparelho telefônico, atingindo apenas uma parte das atividades de comunicação do investigado, isto é, aquelas que envolvem utilização do aparelho telefônico. Por sua vez, uma interceptação ambiental é voltada para conversas sem intermediação, entre pessoas presentes, e capta substancialmente e amplamente mais uma comunicação, abrangendo monólogos e outras conversas presenciais antes, durante ou depois de cada conversa telefônica que pode ter feito, podendo se estender não só a aspectos orais, mas também visuais e eletromagnéticos, enriquecendo ainda mais o universo de informações obtidas.

Em segundo lugar, quanto ao meio operacional de realizar a interceptação: enquanto na ambiental há necessidade de diligências anteriores, como o prévio ingresso dissimulado de agentes públicos no local para a instalação do equipamento necessário para captar os sinais acústicos, ópticos ou eletromagnéticos, na interceptação telefônica não há tal necessidade, já que ela ocorre, em geral, com o auxílio direto de empresas de telefonia. Não há na Lei n. ${ }^{\circ}$ 9.296/1996 disciplina do meio operacional prévio, que pode inclusive ser em domicílio. Assim, essa fase anterior fica numa espécie de limbo jurídico ${ }^{31}$, carecendo regulamentação em lei.

Nesse contexto, a interceptação ambiental mostra-se uma medida investigativa mais invasiva e que exige cuidados regulatórios específicos.

31 MALAN, Diogo. Da Captação Ambiental de sinais eletromagnéticos, óticos, ou acústicos e os limites relativos à privacidade. AMBOS, Kai; ROMERO, Eneas (coord.). Crime Organizado: Análise da Lei 12. 850/2013. São Paulo: Marcial Pons, 2017. p. 51-81. p. 67. 
A transposição de previsões como a do artigo $3^{\circ}$ da Lei das Interceptações Telefônicas, que fala em decretação de ofício da medida, ou do artigo $4^{\circ}$, $\S 1^{\circ}$, que permite, mesmo que excepcionalmente, o requerimento verbal, é criticável, tendo em vista o caráter excepcional e invasivo da privacidade da interceptação ambiental. Permitir decreto de ofício ou verbalmente impediria uma análise detida da fundamentação da decisão judicial, além de, no primeiro caso, chocar-se com o princípio acusatório. Mais do que isso, deixar a questão do prazo e de sua prorrogação, nos termos do artigo $5^{\circ}$, em aberto cria amplas possibilidades de uso irrazoável.

Sendo assim, mostra-se problemática e insuficiente a aplicação analógica da Lei n. ${ }^{0}$ 9.296/1996 à interceptação ambiental na linha do entendimento de Malan e Arantes Filho ${ }^{32}$, sobretudo de uma perspectiva garantista. Com efeito, na situação atual do instituto, fere o princípio da legalidade probatória a utilização dessa prova atípica que atinge direitos fundamentais e que não goza de procedimento que possa lhe ser analogicamente aplicado de forma apropriada, a fim de embasar a sua execução. Em regra, essa conclusão jurídica deveria significar que o magistrado, ao deparar-se com um requerimento policial ou ministerial de interceptação ambiental, deveria negá-lo, sob pena de ilicitude probatória e consequente nulidade do processo. Caso fosse aceita, deveria ser declarada nula e desentranhada dos autos.

\section{REGULAMENTAÇÃO: AS LIÇÕES DO TRIBUNAL EUROPEU DE DIREITOS HUMANOS}

No item anterior, concluímos que a interceptação ambiental afeta direitos fundamentais e que a Lei de Interceptações Telefônicas se mostra inapta para ser aplicada analogicamente. Vimos também que a jurisprudência brasileira admite tal medida, sempre que autorizada judicialmente. No entanto, isso não significa que o instituto deva ficar

32 C.f. MALAN, Diogo. Da Captação Ambiental de sinais eletromagnéticos, óticos, ou acústicos e os limites relativos à privacidade. AMBOS, Kai; ROMERO, Eneas (coord.). Crime Organizado: Análise da Lei 12. 850/2013. São Paulo: Marcial Pons, 2017. p. 51-81, p. 67 e ARANTES FILHO, Marcio Geraldo Britto. A interceptação de comunicação entre pessoas presentes. Brasília: Gazeta Jurídica, 2013. p 296. 
sem regulamentação legislativa; pelo contrário, para coibir arbítrios do poder público que atentem a direitos constitucionalmente assegurados é que é necessário preencher a omissão legislativa nessa área.

Por conta disso, essa seção buscará na jurisprudência do Tribunal Europeu de Direitos Humanos quanto aos direito à vida privada e familiar, disposto no artigo $8^{\circ}$ da Convenção para a Proteção dos Direitos do Homem e das Liberdades Fundamentais de $1950^{33}$, lições para a regulamentação de interceptações ambientais. Acreditamos que ela oferece caminhos e orientações sobre o tipo de regime regulatório a que a medida deve estar submetida, bem como sobre o tipo de análise que deve ser feito a nível concreto para que possa ser deferida e utilizada de forma compatível com a proteção a direitos fundamentais. ${ }^{34}$

Por mais que haja um certo grau de autonomia dos países na regulamentação dos meios de investigação de provas ocultos, como é o caso da interceptação ambiental, é necessário que todos os procedimentos considerados invasivos ao direito consagrado no artigo $8^{\circ}$ da Convenção sigam uma mesma base para evitar arbítrios ${ }^{35}$, na forma delineada no ponto 8.2 do dispositivo.

33 “ARTIGO $8^{\circ}$ Direito ao respeito pela vida privada e familiar

1. Qualquer pessoa tem direito ao respeito da sua vida privada e familiar, do seu domicílio e da sua correspondência. 2. Não pode haver ingerência da autoridade pública no exercício deste direito senão quando esta ingerência estiver prevista na lei e constituir uma providência que, numa sociedade democrática, seja necessária para a segurança nacional, para a segurança pública, para o bem - estar económico do país, a defesa da ordem e a prevenção das infracções penais, a protecção da saúde ou da moral, ou a protecção dos direitos e das liberdades de terceiros."

34 A escolha metodológica pelos julgados da Corte Europeia de Direitos Humanos se deu pelo fato de seus julgados constituírem paradigma na área de Direitos Humanos Internacional. Isso pode ser constatado quando, em julgados da Corte Interamericana de Direitos Humanos, por exemplo, decisões do TEDH são utilizadas como argumento de autoridade na fundamentação de conceitos que a própria $\mathrm{CADH}$ traz em seus casos. Vide o caso Escher e outros vs. Brasil, de 06 de julho de 2009, em que a CADH, ao tratar da legalidade da previsão das interceptações, utiliza dois casos da TEDH como referência para justificar a necessidade da lei clara e precisa sobre ingerências nos direitos humanos (CORTE INTERAMERICANA DE DIREITOS HUMANOS. Caso Escher e outros vs. Brasil. Sentença de 06.07.09, Parágrafo 127. Disponível em < http://www.corteidh. or.cr/docs/casos/articulos/seriec_200_por.pdf>. Acesso em: 01 set. 2019).

35 C.f. UBERTIS, Giulio. Principi di Procedura Penale europea: Le regole del giusto processo. $2^{\text {a }}$ ed. Milão: Rafaello Cortina Editore, 2009. p. 125 e ss. 
Nesse contexto, segundo Malan, em suas decisões, o TEDH adota a seguinte metodologia: primeiramente, verifica se no caso em concreto houve real restrição ao direito à vida privada e familiar; se é identificada violação, a seguir a Corte examina se a medida restritiva utilizada estava em conformidade ou não com a legislação do Estado parte; tendo sido identificada violação ou não, o TEDH avaliará também, por fim, a necessidade daquela medida no âmbito de uma sociedade democrática ${ }^{36}$ no caso concreto.

Assim, quanto aos requisitos específicos das medidas restritivas a direitos fundamentais, o primeiro está no próprio artigo 8.2 da Convenção: a reserva legal. Exige-se que o meio de investigação sigiloso tenha previsão legal dentro do Estado parte.

Quanto a este aspecto da legalidade, há três decisões relevantes do TEDH aos propósitos deste artigo e que foram proferidas no contexto de interceptações telefônicas. Segundo se depreende dos casos Valenzuela Contrera vs. Espanha ${ }^{37}$, Kruslin vs. França ${ }^{38}$ e Huvig vs. França ${ }^{39}$, há uma delimitação do que se entende por previsão legal no ordenamento, a fim de regulamentar suficientemente os meios de investigação de prova que venham a ferir a privacidade. Para que atenda ao requisito da reserva legal, os seguintes aspectos devem ser observados: (i) determinação dos sujeitos que podem sofrer a interceptação da comunicação telefônica por decisão judicial; (ii) definição da natureza das infrações penais que autorizariam a utilização de tal medida; (iii) determinação do prazo de duração da interceptação; e (iv) criação dos procedimentos para a elaboração dos relatórios de transcrição, de encaminhamento da mídia original integral das gravações, intacta, para o juiz e para as partes, (para fins de controle da integridade da prova), além dos protocolos sobre as circunstâncias nas quais serão apagadas partes das gravações ou até destruída a mídia, especialmente quando houver sentença absolutória.

36 MALAN, Diogo. Da Captação Ambiental de sinais eletromagnéticos, óticos, ou acústicos e os limites relativos à privacidade. AMBOS, Kai; ROMERO, Eneas (coord.). Crime Organizado: Análise da Lei 12. 850/2013. São Paulo: Marcial Pons, 2017. p. 51-81. p. 70-71.

37 TEDH, caso Valenzuela Contrera vs. Espanha, julgado em 30.07.1998

38 TEDH, caso Kruslin vs. França, julgado em 20.04.1990

39 TEDH, caso Huvig vs. França, julgado em 20.04.1990 
Baseado nesses standards, em 2000, o TEDH reconheceu violação ao artigo $8^{\circ}$ no caso Khan vs. Reino Unido ${ }^{40}$, no qual a polícia inglesa realizou uma interceptação domiciliar sem a devida regulamentação do instituto no ordenamento local. Como feriu a reserva legal, não havia como reconhecer a legalidade da captação de sinais acústicos dentro do domicílio do investigado.

Depois da reserva legal, deve ser analisada a estrita necessidade dessa medida no âmbito de uma sociedade democrática, nos termos do art. 8.2 da Convenção ${ }^{41}$. A análise é dividida em três requisitos: idoneidade, necessidade e proporcionalidade em sentido estrito. Quanto ao primeiro, exige-se que a medida seja apta ou adequada a atingir os objetivos propostos no caso concreto: proteção da segurança nacional, da segurança pública e do bem-estar econômico do país, defesa da ordem, prevenção das infrações penais, proteção da saúde ou da moral ou a proteção dos direitos e das liberdades de terceiros. No segundo ponto, deve ser avaliado se há medidas alternativas que menos restringem o direito à vida privada e familiar. No terceiro ponto, por sua vez, deve ser feita uma análise de ponderação de interesses conflitantes: entre o direito à vida íntima e familiar e as finalidades do artigo 8.2 que o Estado deve garantir em decorrência de uma persecução penal. A Corte então analisa no caso concreto se a intensidade da restrição ao direito guarda razoabilidade e proporcionalidade com a relevância do interesse perseguido pelo Estado.

Tudo isso deve ser acompanhado, conforme decisão tomada pelo TEDH, no caso Lambert vs. França ${ }^{42}$, de instrumentos processuais idôneos para que o cidadão alvo de medida restritiva, como a interceptação ambiental, possa se defender. Na legislação do Estado parte, para que a medida possa ser considerada legal e proporcional, deve haver no ordenamento algum meio de controle processual da legalidade, seja ele uma nulidade a ser alegada, ou alguma forma de recurso por parte do investigado, a fim de evitar abusos em seu uso.

\footnotetext{
40 TEDH, Caso Khan vs. Reino Unido, julgado em 12.05.2000

41 MALAN, Diogo. Da Captação Ambiental de sinais eletromagnéticos, óticos, ou acústicos e os limites relativos à privacidade. AMBOS, Kai; ROMERO, Eneas (coord.). Crime Organizado: Análise da Lei 12.850/2013. São Paulo: Marcial Pons, 2017. p. 51-81. p. 72.

42 TEDH, Lambert vs. França, julgado em 24.08.1998
} 


\section{ANÁLISE DO PROJETO DE LEI ANTICRIME ENQUANTO TENTATIVA DE REGULAMENTAÇÃO}

Tendo sida apresentada a jurisprudência do TEDH, volta-se a atenção ao Brasil. No início de 2019, o Ministro da Justiça Sérgio Moro apresentou um projeto de lei ao Congresso Nacional, cunhado de "Projeto Anticrime" (Projeto de Lei n. ${ }^{\circ} 882 / 2019$ ), com o intuito de recrudescer o combate a criminalidade, em especial a organizada. A proposta modificaria diversos diplomas legislativos brasileiros. Para o que nos interessa, altera a Lei n. ${ }^{\circ} 12.850 / 2013$, prevendo nova redação do artigo $3^{\circ}$ sobre as hipóteses de cabimento dos meios de obtenção de prova previstos na lei, e inserindo os artigos 21-A e 21-B por meio da Seção VI, regulando a captação ambiental de sinais ópticos, acústicos e eletromagnéticos. Com base nas observações discutidas até aqui, essa seção analisa criticamente essa parte do projeto.

Atualmente, a redação prevista no artigo $3^{\circ}$ permite o uso do rol de meios de obtenção de prova em qualquer fase da persecução penal, sem prejuízo de outros já previstos em lei. Ao não restringir o deferimento apenas à fase preliminar de investigação, o artigo não se atenta quanto ao caráter sigiloso e cautelar dos meios de obtenção de prova, que permite apenas a hipótese de contraditório diferido. $\mathrm{Na}$ ação penal, momento processual em que as partes já estão definidas e a produção de prova deve respeitar o contraditório pleno a fim de concretizar a ampla defesa do réu, não se pode permitir a investigação sub-reptícia, ao arrepio dos direitos e garantias processuais dele.

O Projeto Anticrime não corrige esse problema e ainda propõe uma nova redação ${ }^{43}$ que aumenta o espectro de incidência para além dos crimes de organização criminosa. O texto legal proposto permite o uso dos meios de obtenção de prova lá previstos e, portanto, de interceptações ambientais, não apenas na investigação de infrações penais praticadas por organizações criminosas, mas também em todas aquelas cujas penas

43 “Art. 3o Em qualquer fase da investigação ou da persecução penal de infrações penais praticadas por organizações criminosas, de infrações penais cujas penas máximas sejam superiores a 4 (quatro) anos ou de infrações penais conexas, serão permitidos, sem prejuízo de outros já previstos em lei, os seguintes meios de obtenção da prova:" 
máximas sejam superiores a quatro anos, ou em infrações conexas. Da perspectiva aqui avançada, considerando-se o nível de restrição a direitos fundamentais que interceptações ambientais podem acarretar e o contexto da reforma, o dispositivo deveria ser revisto para se conter apenas a crimes praticados por organização criminosa. Na forma como está, a proposta tem potencial de multiplicar diversos outros problemas do projeto para diversas outras investigações. É o que se passa a ver.

O caput do artigo 21- $\mathrm{A}^{44}$ prevê a possibilidade do uso do meio de obtenção de prova na fase de investigação ou instrução criminal, desde que autorizada pela autoridade judicial, mediante requerimento da autoridade policial ou ministerial. Aqui temos uma escolha legislativa clara por permitir o requerimento direto pela autoridade policial, sem passar pelo crivo ministerial anterior. Ocorre que o Ministério Público é o titular da ação penal nos termos do artigo 129, I, da Constituição Federal e somente ele que pode avaliar se é o caso ou não de requerer tal medida para a obtenção da justa causa para o oferecimento da denúncia, representando quando encontrar necessidade, fundamentada, de que precisa de acervo probatório consistente a fim de dar subsidiariedade à denúncia. Assim, ao nosso ver, nos casos em que a autoridade policial se manifesta nesse sentido, o Ministério Público deveria ter de oferecer parecer endossando ou negando tal pedido endereçado ao juiz.

Nos incisos do artigo 21-A estão listadas as condições necessárias que precisam estar presentes para que a medida possa ser autorizada: (i) a prova não puder ser obtida por outros meios disponíveis e igualmente eficazes; (ii) houver elementos de prova razoáveis de autoria ou participação em infrações criminais cujas penas ultrapassam quatro anos ou em casos de infrações conexas. Como se depreende, traz dispositivo similar ao artigo $2^{\circ}$ da Lei n. ${ }^{\circ}$ 9.296/1996, com a diferença de que esta limita o uso da medida a investigações de crimes puníveis com reclusão, ao passo

44 “Art. 21-A. Para investigação ou instrução criminal, poderá ser autorizada pelo juiz a requerimento da autoridade policial ou do Ministério Público a captação ambiental de sinais eletromagnéticos, ópticos ou acústicos, quando: I - a prova não puder ser feita por outros meios disponíveis e igualmente eficazes; e II - houver elementos probatórios razoáveis de autoria e participação em infrações criminais cujas penas máximas sejam superiores a quatro anos ou em infrações penais conexas." 
que as interceptações ambientais estariam restritas aos crimes cuja pena máxima seja superior a quatro anos.

Nesta proposta de dispositivo, há avanços, diante da absoluta falta de regulamentação que a interceptação ambiental possui. O delineamento de requisitos hoje não existe na Lei n. ${ }^{\circ}$ 12.850/2013, deixando espaços para arbítrios tanto na elaboração de pedidos quanto na concessão de autorizações judiciais e trazendo insegurança quando à legalidade da prova assim obtida. Assim, elencar requisitos formais e materiais é positivo. Dito isso, cabe notar que a lei não menciona explicitamente que a autorização judicial seja fundamentada. Não precisaria, já que se trata de comando obrigatório por força constitucional (art. 93, IX). Apesar disso, o reforço acentuaria a exigência de que a medida só pode ser utilizada quando efetivamente justificada. Neste aspecto, seria positivo se houvesse maior clareza quanto às etapas de fundamentação a que a decisão judicial deve atender para evitar que a medida seja deferida com base na menção de que os requisitos foram atendidos - algo como hoje existe no art. $10 \mathrm{da}$ Resolução $n^{0}$ 59/2008 (na redação dada pela Resolução $n^{\circ} 217 / 2016$ ) do CNJ para interceptações telefônicas, por exemplo. Também valeria a exigência explícita de que o contexto e a extensão da interceptação ambiental fossem delimitados de forma circunstanciada na decisão judicial.

Dando continuidade, o artigo possui seis parágrafos. $\mathrm{O} \S 1^{\mathrm{o45}}$ estipula que o requerimento ministerial ou policial deve descrever de modo detalhado o local e a forma de instalação do dispositivo de captação, enquanto o $\$ 2^{046}$ permite que a instalação do equipamento pode ser realizada, quando necessária, no período noturno ou por meio de operação policial disfarçada.

Esse conjunto de parágrafos merece análise detida. A mera menção a um procedimento prévio de inserção de equipamento e a exigência de que a autoridade policial ou o Ministério Público descrevam de modo detalhado o local e a forma de instalação do material de captação podem não ser suficientes para atender as preocupações discutidas anteriormente.

45 “\$10 O requerimento deverá descrever circunstanciadamente o local e a forma de instalação do dispositivo de captação ambiental."

46 “\$2o A instalação do dispositivo de captação ambiental poderá ser realizada, quando necessária, no período noturno ou por meio de operação policial disfarçada." 
Melhor seria especificar e restringir, na própria lei, o agir da polícia quanto à instalação dos aparelhos de captação, impedindo excessos, especialmente nos casos mais invasivos - como o da interceptação ambiental domiciliar. A lei não baliza nem diferencia o que considera uma instalação legal de equipamentos em espaço público ou fechado, deixando isso a mercê da autoridade policial e do promotor de justiça, por exemplo.

Curiosa - e possivelmente mais temerária - é a expressão “quando necessária” presente no $\S 2^{\circ}$. A instalação de equipamentos no período noturno ou mediante operação encoberta policial é medida de extrema gravidade, pois representa em si uma invasão e uma fraude. Nesse sentido, a entrada noturna ou sub-reptícia deveria estar melhor delimitada na lei, inserindo inclusive parâmetros mais específicos - como, por exemplo, a exigência de que fosse demonstrada a impossibilidade de instalação por outros modos e a apresentação de relatório circunstanciado acerca do modo de instalação, para permitir alguma instância de controle e responsabilização por eventuais abusos.

Nos termos do parágrafo $\$ 3^{047}$, a captação ambiental não pode ultrapassar quinze dias, podendo ser renovada por igual período mediante decisão judicial, frise-se, fundamentada, quando comprovadas (i) a imprescindibilidade da medida para a continuidade da investigação, e (ii) a presença de criminalidade permanente, habitual ou continuada. Trata-se de um avanço, dada a abertura que hoje existe.

Em seguida, o $\S 4^{\mathrm{o} 48}$ traz a figura da gravação clandestina feita por um dos interlocutores, sem autorização judicial prévia nem mesmo prévio conhecimento de autoridade policial ou ministerial. Tema antes restrito a decisões judiciais ${ }^{49}$, o dispositivo legalizaria o instituto, desde

47 “ $\$ 3^{\circ}$ A captação ambiental não poderá exceder o prazo de quinze dias, renovável por decisão judicial por iguais períodos, se comprovada a indispensabilidade do meio de prova e quando presente atividade criminal permanente, habitual ou continuada."

$48 \S 4^{\circ}$ A captação ambiental feita por um dos interlocutores sem o prévio conhecimento da autoridade policial ou do Ministério Público poderá ser utilizada como prova de infração criminal quando demonstrada a integridade da gravação."

49 O Supremo Tribunal Federal, em repercussão geral reconhecida na Questão de Ordem do RE 583937, de relatoria do Ministro Cezar Peluso, julgado em 19/11/2009, decidiu pela licitude da utilização da gravação clandestina por 
que comprovada a integridade da gravação. Entretanto, vale observar que, na jurisprudência, era permitida a utilização como prova apenas em favor do interlocutor que realizou a gravação, em prol do seu direito de defesa, e para compor conduta criminosa alheia, como nos casos de extorsão, por exemplo, quando a vítima grava o autor sem o seu conhecimento a fim de demonstrar para as autoridades policiais a ocorrência do crime. Entendemos que o mesmo entendimento deve ser mantido na interpretação deste parágrafo, sempre de maneira restritiva.

Por sua vez, o $\S 5^{050}$ prevê que se aplicam os artigos da Lei de Interceptações Telefônicas ao disposto no artigo 21-A de interceptação ambiental. Conforme visto, entendemos que essa aplicação estaria restrita apenas àquilo que for cabível e não atentar contra direitos fundamentais, uma vez que o uso de analogia nesses casos esbarra em uma série de problemas. De todo modo, vale apontar que a extensão por analogia importa para as interceptações ambientais alguns problemas já presentes na Lei n. ${ }^{0} 9.296 / 1996^{51}$ : para ficar em um exemplo, cabe citar a questão do incidente de inutilização de gravações que não interessem à prova acusatória. O parágrafo único do art. $9^{\circ}$ daquela lei determina que 0 incidente deve ser assistido pelo parquet, mas a presença do acusado ou de seu representante legal é facultativa. Essa opção legislativa é alvo de críticas, uma vez que a discussão de retirada ou não de trechos da conversa interceptada, para que tenha legitimidade frente aos ditames constitucionais, deveria ser feita sempre sob a égide do contraditório ${ }^{52}$,

uma das partes, consolidando o Tema 237, e a tese de que quando feita por um dos interlocutores, sem conhecimento dos outros, a prova é lícita.

"§ $5^{\circ}$ Aplicam-se subsidiariamente à captação ambiental as regras previstas na legislação específica para a interceptação telefônica e telemática.”

Outras questões em aberto são discutidas, por exemplo, em: SANTORO, Antonio E. R.; TAVARES, Natália L. F.; GOMES, Jefferson C. O protagonismo dos sistemas de tecnologia da informação na interceptação telefônica: a importância da cadeia de custódia. Revista Brasileira de Direito Processual Penal, Porto Alegre, vol. 3, n. 2, p. 605-632, mai./ago., 2017. https:/doi.org/10.22197/ rbdpp.v3i2.76.

52 MALAN, Diogo. Da Captação Ambiental de sinais eletromagnéticos, óticos, ou acústicos e os limites relativos à privacidade. AMBOS, Kai; ROMERO, Eneas (coord.). Crime Organizado: Análise da Lei 12. 850/2013. São Paulo: Marcial Pons, 2017. p. 51-81. p. 61. e BADARÓ, Gustavo. Processo Penal. $4^{\text {a }}$ ed. São Paulo: Revista dos Tribunais, 2015. p. 519. 
com a presença pelo menos da defesa técnica do investigado, a fim de impedir que conversas sem relação com os fatos, de caráter íntimo, sejam juntadas aos autos. Isso permitiria inclusive que terceiro, vindo a saber de conversas suas interceptadas com o investigado, seja tomando conhecimento pelo próprio, ou pelo seu defensor, pudesse requisitar a inutilização do trecho caso não seja útil ao acervo probatório ${ }^{53}$. Nesse contexto, a imposição da aplicação analógica da Lei n. ${ }^{0}$ 9.296/1996 às captações ambientais deixa de corrigir velhos problemas: ao invés de aproveitar a oportunidade para garantir acesso pela defesa técnica ao incidente de inutilização no caso de interceptações ambientais, a fim de que se possa exercer o contraditório e impedir que conversas sem conteúdo relevante para com a investigação sejam juntadas expondo a intimidade dos interlocutores desarrazoadamente, apenas se expande uma fragilidade de modelo regulatório atual.

Feita essa observação e voltando ao projeto, no $§ 6^{054}$ do art. 21-A há previsão de que não há necessidade de decisão judicial nos casos em que houver a interceptação ambiental óptica em locais abertos ao público. A restrição contida no texto é de que a permissão se aplica a captações exclusivamente ópticas - não podendo abranger sinais acústicos, o que é uma limitação bem-vinda. Ainda assim, falta aqui um cuidado maior. $\mathrm{O}$ dispositivo trabalha com a velha (e ultrapassada) noção de que não existe privacidade em ambientes públicos e, diante da emergência do direito à autodeterminação informacional, que resguarda indivíduos também em público, tentar dar completa imunidade à medida. Assim confere, de modo criticável ${ }^{55}$, ampla discricionariedade à autoridade policial, que não teria de comprovar indícios de envolvimento de alvos em quaisquer atividades criminosas nem prestar contas dessa diligência. De todo modo,

53 BADARÓ, Gustavo. Processo Penal. $4^{\mathrm{a}}$ ed. São Paulo: Revista dos Tribunais, 2015. p. 519-520.

54 " $\$ 6^{\circ}$ A captação ambiental de sinais ópticos em locais abertos ao público não depende de prévia autorização judicial."

55 Ver também ANTONIALLI, Dennys; FRAGOSO, Nathalie; MASSARO, Heloísa. Da investigação ao encarceramento: as propostas de incremento do uso da tecnologia no Projeto de Lei Anticrime. Disponível em: <https://www. ibccrim.org.br/boletim_artigo/6337-Da-investigacao-ao-encarceramento-as-propostas-de-incremento-do-uso-da-tecnologia-no-Projeto-de-Lei-Anticrime.>. Acesso em: 01 set. 2019. 
em qualquer leitura, não se pode extrair desse dispositivo uma autorização para usos irrestritos e sem balizas de câmeras com reconhecimento facial em áreas públicas, por exemplo. O uso desse tipo de ferramenta em si, pelos problemas específicos de vieses e falsos positivos, deve ser cuidadosamente debatido e apenas eventualmente regulamentado, ${ }^{56} \mathrm{de}$ modo que a alteração da redação para uma manifestação clara nesse sentido pode demonstrar mais respeito a direitos.

Por fim, o artigo 21-B ${ }^{57}$ prevê um novo tipo penal para as captações ambientais sem autorização judicial, quando permitida (aqui, abarcando o permissivo do $\S 6^{\circ}$ ), com pena de reclusão de dois a quatro anos, e multa. $\mathrm{O} \S 1^{\circ}$ exclui a ilicitude da pessoa que realiza a gravação clandestina. Já o $\S 2^{\circ}$ determina que incorre na mesma pena o funcionário público que descumpra a determinação de sigilo da captação ambiental ou revelar o conteúdo das gravações antes do sigilo ser levantado.

A proposta analisada para por aí. Mas é possível imaginar outros pontos que uma regulamentação deveria enfrentar, com base nos direitos fundamentais afetados: Quando é admissível a interceptação ambiental em recintos em que o acusado não tem domicílio? Qual proteção a ser dada a terceiros não diretamente suspeitos? Como lidar com a questão do sigilo profissional de certas categorias? A prova obtida por interceptação ambiental pode ser emprestada a processos cíveis, administrativos, eleitorais? Qual o tratamento a ser dado à mídia original da captação?

Ao lado desses pontos, alguns delineamentos realizados pelo Tribunal Europeu de Direitos Humanos nos julgamentos sobre meios de

56 Para um sucinto panorama das discussões, ver BIONI, Bruno; RIELLI, Mariana; LUCIANO, Maria. Regulação de reconhecimento facial em São Francisco, Jota, 25 de junho de 2019. Disponível em: https://www.jota.info/opiniao-e-analise/colunas/agenda-da-privacidade-e-da-protecao-de-dados/ regulacao-de-reconhecimento-facial-em-sao-francisco-25062019. Acesso em: 08 set. 2019.

57 “Art. 21-B. Realizar captação ambiental de sinais eletromagnéticos, ópticos ou acústicos para investigação ou instrução criminal sem autorização judicial, quando esta for exigida. Pena - reclusão, de 2 (dois) a 4 (quatro) anos, e multa. $\S 1^{\circ}$ Não há crime se a captação é realizada por um dos interlocutores. $\S 2^{\circ}$ Incorre na mesma pena o funcionário público que descumprir determinação de sigilo das investigações que envolvam a captação ambiental ou revelar o conteúdo das gravações enquanto mantido o sigilo judicial.” 
investigação de prova ocultos podem trazer interessantes contribuições quanto a uma possível regulamentação de uma potencial legislação sobre o instituto. A exigência de reserva legal, principalmente, para a medida atentatória a direitos fundamentais e a devida regulamentação legislativa para o procedimento são necessários para cumprir a garantia ao procedimento do investigado, em nome da segurança jurídica. Mais do que isso, exigir que haja na lei instrumentos de defesa para o cidadão investigado é importantíssimo para garantir a ampla defesa e o contraditório e evitar arbítrios estatais durante a investigação.

\section{CONCLUSÃO}

O presente artigo analisou o status das interceptações ambientais como medida investigativa no direito brasileiro e identificou pontos que devem ser endereçados para que possa ser considerada compatível com direitos fundamentais. O diagnóstico, aqui limitado ao caso das interceptações ambientais, oferece um retrato de como instrumentos tecnológicos que estão sendo incorporados à prática do direito processual penal merecem detida análise de constitucionalidade e legalidade. Nesse sentido, vimos que a interceptação ambiental, enquanto meio de investigação de prova, é nominada na Lei n. ${ }^{0}$ 12.850/2013, mas atípica, por não ter regulamentação específica na mesma lei ou em outra. Pelas suas especificidades, em respeito a direitos fundamentais, consideramos que não é suficiente a aplicação análoga da Lei n. ${ }^{0}$ 9.296/1996 nem muito menos a mera existência de autorização judicial para que a medida seja válida. Contudo, isso não têm impedido que a medida seja declarada legal pela jurisprudência.

A seguir, voltamo-nos à jurisprudência e lições do Tribunal Europeu de Direitos Humanos com relação a restrições ao direito à vida privada e à interceptação ambiental para encontrar referências acerca dos ajustes que devem ser feitos no quadro regulatório e na prática jurídica brasileira. Como se viu, o Tribunal destaca o princípio da reserva legal: interceptações ambientais devem ser objeto de cuidadosa regulamentação. Em casos concretos, a aplicação dos parâmetros legais deve ser combinada com uma análise rigorosa da pertinência e da proporcionalidade da medida. 
Por fim, verificamos que o Projeto de Lei Anticrime traz diversos elementos que podem ser vistos como avanços - notadamente porque hoje não há nada além do que menção à medida em lei. Assim, o fato de que se propõe elencar requisitos formais e materiais, por exemplo, já é um progresso. Ao mesmo tempo, o projeto é tímido no seu esforço de demonstrar um comprometimento com direitos fundamentais e é quase integralmente permeado por problemas que podem levar ao ou agravar o descontrole sobre o uso da medida. Nesse cenário, o caso das interceptações ambientais ensina que, para se elevar à revolução tecnológica sem admitir erosão de direitos, a prática jurídica brasileira tem um longo caminho a percorrer.

\section{BIBLIOGRAFIA}

ABREU, Jacqueline de Souza; ANTONIALLI, Dennys. Vigilância sobre as comunicações no Brasil: interceptações, quebras de sigilo, infiltrações e seus limites constitucionais. InternetLab: São Paulo, 2017.

ALEXY, Robert. Teoria dos Direitos Fundamentais. $2^{\mathrm{a}}$ ed. São Paulo: Malheiros, 2015.

ALEXY, Robert. Constitutional Rights and Proportionality. Revus (Online), v. 22, p. 51-65, 2014. Disponível em: <http://revus.revues.org/2783>. Acesso em: 01. set. 2019. https://doi.org/10.4000/revus.2783

ANTONIALLI, Dennys; FRAGOSO, Nathalie; MASSARO, Heloísa. Da investigação ao encarceramento: as propostas de incremento do uso da tecnologia no Projeto de Lei Anticrime. Disponível em: <https://www.ibccrim.org.br/boletim_artigo/ 6337-Da-investigacao-ao-encarceramento-as-propostas-de-incremento-do-uso-da-tecnologia-no-Projeto-de-Lei-Anticrime.>. Acesso em: 01 set. 2019.

ARANTES FILHO, Marcio Geraldo Britto. A interceptação de comunicação entre pessoas presentes. Brasília: Gazeta Jurídica, 2013.

ARANHA, Adalberto José de Camargo. Da Prova no Processo Penal. $7^{\mathrm{a}}$ ed. São Paulo: Saraiva, 2008.

AVOLIO, Luis Francisco. Provas ilícitas: interceptações telefônicas, ambientais e gravações clandestinas. $3^{\mathrm{a}}$ ed. São Paulo: Revista dos Tribunais, 2003.

BADARÓ, Gustavo. Editorial do dossiê "Prova penal: fundamentos epistemológicos e jurídicos”. Revista Brasileira de Direito Processual Penal, Porto Alegre, vol. 4, n. 1, p. 43-80, 2018. http://dx.doi.org/10.22197/rbdpp.v4i1.138 
BADARÓ, Gustavo. Hipóteses que autorizam o emprego de meios excepcionais de obtenção de prova. In: AMOS, Kai; ROMERO, Eneas (orgs.). Crime Organizado: Análise da Lei 12.850/13. Marcial Pons: Madri, 2017. p. 13-49.

BADARÓ, Gustavo. Interceptação de comunicações telefônicas e telemáticas: limites ante o avanço da tecnologia. In: LIMA, José Corrêa de; CASARA, R. R. Rubens. (coord.). Temas para uma perspectiva crítica do direito: homenagem ao Professor Geraldo Prado. Rio de Janeiro: Lumen Juris, 2010. p. 483-499.

BADARÓ, Gustavo. Processo Penal. 4a ed. São Paulo: Revista dos Tribunais, 2015. BIONI, Bruno; RIELLI, Mariana; LUCIANO, Maria. Regulação de reconhecimento facial em São Francisco, Jota, 25 de junho de 2019. Disponível em: https://www. jota.info/opiniao-e-analise/colunas/agenda-da-privacidade-e-da-protecao-de-dados/regulacao-de-reconhecimento-facial-em-sao-francisco-25062019. Acesso em: 08 set. 2019

CABETTE, Eduardo Luiz Santos. Gravações Clandestinas e Ambientais: tutela constitucional da intimidade e os agentes públicos. Boletim IBCCRIM, São Paulo, n. 65 , p. 5-6, 1998.

CARMONA, Claudia. Le intercettazioni ambientali in relazione allá normative del 1991 sui reati di criminalità organizata. Rivista Italiana di Diritto e Procedura Penale, v. 42, n.1, p. 352-358, 1999.

CUNHA JÚNIOR, Dirley da. Curso de Direito Constitucional. $7^{\mathrm{a}}$ ed. Salvador: Juspodivm, 2013.

DEZEM, Guilherme Madeira. Da prova penal: tipo processual, provas típicas e atípicas: (atualizado de acordo com as Leis 11.689/08, 11.690/08 e 11.719/08). Campinas: Millenium, 2008.

DEZEM, Guilherme Madeira. Curso de Processo Penal. São Paulo: Revista dos Tribunais, 2015.

MARTINO, Corrada di. Le intercettazioni ambientali. L'Indice Penale, Verona, v. 6, n. 3, p. 1.147-1.171, set./dez. 2003.

FERRAZ JR., Tercio Sampaio, Sigilo de Dados: o direito à privacidade e os limites da função fiscalizadora do Estado. Revista da Faculdade de Direito da Universidade de São Paulo, São Paulo, v. 88, p. 439-459, 1993.

DONEDA, Danilo. Da privacidade à proteção de dados pessoais. São Paulo: Renovar, 2006.

GRINOVER, Ada Pellegrini; GOMES FILHO, Antonio Magalhães; FERNANDES, Antonio Scarance. As nulidades no processo penal. $11^{\mathrm{a}}$ ed. São Paulo: Revista dos Tribunais, 2009. 
HAIRABEDIÁN, Maximiliano. La grabación como prueba en el proceso penal. Pensamiento penal y criminológico: Revista de derecho penal integrado, Córdoba, $\mathrm{v}$. 3, n. 4, p. 119-150, 2002.

FERNANDES, Antonio Scarance. O equilíbrio entre a eficiência e o garantismo e o crime organizado. Revista Brasileira de Ciências Criminais, São Paulo, v. 16, n. 70, p. 229-268, jan./fev. 2009.

FERNANDES, Antonio Scarance. Teoria Geral do Procedimento e o Procedimento no Processo Penal. São Paulo: Revista dos Tribunais, 2005.

FONSECA, Tiago Abud da. Interceptação telefônica: a devassa em nome da lei. Rio de Janeiro: Espaço Jurídico, 2008.

GOMES, Luiz Flávio. Interceptação telefônica: comentários à lei 9.296, de 24.07.1996. $2^{\mathrm{a}}$ ed. São Paulo: Revista dos Tribunais, 2013.

GOMES FILHO, Antonio Magalhães. Notas sobre a terminologia da prova (reflexos no processo penal brasileiro). In: YARSHELL, Flavio Luiz; MORAES, Maurício Zanoide de (orgs.). Estudos em homenagem à professora Ada Pellegrini Grinover. São Paulo: DPJ, 2005. p. 303-318.

GOMES FILHO, Antonio Magalhães; BADARÓ, Gustavo. Prova e sucedâneos da prova no processo penal brasileiro. Revista Brasileira de Ciências Criminais, São Paulo, v. 15, n. 65, p. 175-208, mar./abr. 2007.

GRECO FILHO, Vicente. Interceptação telefônica: considerações sobre a lei n. 9.296, de 24 de julho de 1996. $2^{\text {a }}$ ed. rev. São Paulo: Saraiva, 2005.

LOPES JÚNIOR, Aury. Direito Processual Penal. 9a ed. São Paulo: Saraiva, 2012.

MALAN, Diogo. Da captação ambiental de sinais eletromagnéticos, óticos ou acústicos e os limites relativos à privacidade In: AMBOS, Kai; ROMERO, Eneas (orgs.). Crime Organizado: Análise da Lei 12.850/13. Marcial Pons: Madri, 2017. p. 51-81.

MALAN, Diogo. Interceptação de comunicações telefônicas: standards dos sistemas interamericano e europeu de direitos humanos. In: SANTORO, Eduardo R. S.; MADURO, Flávio M. Interceptação telefônica: 20 anos da Lei 9.296/96. Belo Horizonte: Editora D’Plácido, 2016. p. 149-174.

MALAN, Diogo. Processo Penal do Inimigo. Revista Brasileira de Ciências Criminais, v. 14, n. 59, p. 223-258, mar./abr. 2006.

MASSON, Cleber; MARÇAL, Vinícius. Crime Organizado. $3^{\text {a }}$ ed. Rio de Janeiro: Forense; São Paulo: Método, 2017.

MENDES, Laura Schertel. Privacidade, proteção de dados e defesa do consumidor. São Paulo: Saraiva, 2014. 
MENDRONI, Marcelo Batlouni. Crime organizado: aspectos gerais e mecanismos legais. 6ª ed. Rio de Janeiro: Forense; São Paulo: Atlas, 2016.

MOORE, Adam D. Privacy Rights: Moral and Legal Foundations. Pennsylvania: Penn State University, 2010.

MUÑOZ CONDE, Francisco. Valoración de las grabaciones audiovisuales em el proceso penal. $2^{\mathrm{a}}$ ed. Buenos Aires: Hammurabi, 2007.

NUCCI, Guilherme de Souza. Organização criminosa: Comentários à Lei 12.850, de 2 de agosto de 2013. São Paulo: Revista dos Tribunais, 2013.

NUCCI, Guilherme de Souza. Leis Penais e Processuais Penais Comentadas. v. 1. $10^{\mathrm{a}}$ ed. Rio de Janeiro: Forense, 2017.

PRADO, Geraldo. Limites às interceptações telefônicas e a jurisprudência do Superior Tribunal de Justiça. Rio de Janeiro: Lumen Juris, 2005.

RANGEL, Paulo. Direito Processual Penal. 18 a ed. Rio de janeiro: Lumen Juris, 2011.

RANGEL, Ricardo Melchior de Barros. A prova ilícita e a interceptação telefônica no direito processual penal brasileiro. Rio de Janeiro: Forense, 2000.

ROXIN, Claus. La proibición de autoincriminación y de las escuchas domiciliarias. Trad. Francisco Muñoz Conde. Buenos Aires: Hammurabi, 2008.

SANTORO, Antonio E. R.; TAVARES, Natália L. F.; GOMES, Jefferson C. O protagonismo dos sistemas de tecnologia da informação na interceptação telefônica: a importância da cadeia de custódia. Revista Brasileira de Direito Processual Penal, Porto Alegre, vol. 3, n. 2, p. 605-632, mai./ago. 2017. https://doi.org/10.22197/ rbdpp.v3i2.76.

SIDI, Ricardo. A interceptação das comunicações telemáticas no processo penal. Belo Horizonte: D’Plácido, 2016.

SILVA, Eduardo Araújo da. Organizações criminosas: aspectos penais e processuais penais da Lei 12.850/13. $2^{\text {a }}$ ed. São Paulo: Atlas, 2017.

SILVA, José Afonso. Curso de Direito Constitucional. 32ª Ed. São Paulo: Malheiros, 2009.

UBERTIS, Giulio. Principi di Procedura Penale europea: Le regole del giusto processo. $2^{\text {a }}$ ed. Milão: Rafaello Cortina Editore, 2009.

ZANELLA, Everton Luiz. Infiltração de agentes no combate ao crime organizado: análise do mecanismo probatório sob o enfoque da eficiência e o garantismo. Curitiba: Juruá, 2016. 


\section{Informações adicionais e declarações dos autores (integridade científica)}

Declaração de conflito de interesses (conflict of interest declaration): os autores confirmam que não há conflitos de interesse na realização das pesquisas expostas e na redação deste artigo.

Declaração de autoria e especificação das contribuições (declaration of authorship): todas e somente as pessoas que atendem os requisitos de autoria deste artigo estão listadas como autores; todos os coautores se responsabilizam integralmente por este trabalho em sua totalidade.

- Jacqueline de Souza Abreu: projeto e esboço inicial, levantamento bibliográfico, revisão bibliográfica, redação, revisão crítica com contribuições substanciais, aprovação da versão final.

- Gianluca Martins Smanio: projeto e esboço inicial, levantamento bibliográfico, revisão bibliográfica, redação, revisão crítica com contribuições substanciais, aprovação da versão final.

Declaração de ineditismo e originalidade (declaration of originality): os autores asseguram que o texto aqui publicado não foi divulgado anteriormente em outro meio e que futura republicação somente se realizará com a indicação expressa da referência desta publicação original; também atestam que não há plágio de terceiros ou autoplágio. 


\section{Dados do processo editorial}

(http://www.ibraspp.com.br/revista/index.php/RBDPP/about/editorialPolicies)

- Recebido em: 10/07/2019

- Controle preliminar e verificação de plágio: Equipe editorial envolvida 12/07/2019

- Avaliação 1: 24/07/2019

- Avaliação 2: 25/07/2019

- Avaliação 3: 27/07/2019

- Decisão editorial preliminar: 27/08/2019

- Retorno rodada de correções: 08/09/2019

- Decisão editorial final: 20/09/2019

\section{COMO CITAR ESTE ARTIGO:}

ABREU, Jacqueline de S.; SMANIO, Gianluca M. Compatibilizando o uso de tecnologia em investigações com direitos fundamentais: o caso das interceptações ambientais. Revista Brasileira de Direito Processual Penal, Porto Alegre, vol. 5, n. 3, p. 1449-1482, set./dez. 2019. https://doi.org/10.22197/rbdpp.v5i3.262

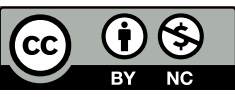

Esta obra está licenciada com uma Licença Creative Commons Atribuição-NãoComercial 4.0 Internacional. 